\title{
VINCULAÇÃO E LIBERDADE DOS REPRESENTANTES POLÍTICOS: ENTRE MANDATO IMPERATIVO E REPRESENTATIVO
}

\author{
POLITICAL REPRESENTANTS BINDING AND FREEDOM: BETWEEN IMPERATIVE END \\ REPRESENTATIVE MANDATE
}

Lucas Catib Laurentiis ${ }^{1}$

\section{Resumo}

Este trabalho busca discutir e analisar as características fundamentais do regime jurídico a que se submetem os detentores do mandato parlamentar. É assim uma pesquisa acerca do que a doutrina denomina "regime jurídico do estatuto parlamentar", ramo do direito público que trata de institutos como: a imunidade e a inviolabilidade dos mandatos parlamentares, a inelegibilidade, o processo de cassação dos detentores de mandatos eletivos, a prerrogativa de foro entre outros temas relevantes à definição do princípio democrático existente na república brasileira. Tais institutos são fundamentais à operacionalização do Estado, sendo possível desenvolver uma pesquisa em apartado para cada um deles. No entanto, sem negligenciar a importância do entendimento doutrinário e jurisprudencial de cada um destes pontos, este trabalho dá um passo atrás e se volta para uma questão de fundo que permeia toda a discussão destes institutos: a relação tensa entre a responsabilidade e a liberdade dos parlamentares.

Palavras Chave: democracia; direito constitucional; autonomia parlamentar; representação política.

\section{A REPRESENTAÇÃO POLÍTICA}

A definição da representação política e de seu papel na caracterização do sistema republicano de governo são temas constantes na literatura política e jurídica. A construção teórica da moderna forma de Estado é resultado direto de discussões e análises desses temas. Autores como Rousseau ${ }^{2}$, Hobbes $^{3}$, Montesquieu $^{4}$ e Stuart Mill ${ }^{5}$ analisaram estes fenômenos políticos e jurídicos sob diversos aspectos. Esta importância foi salientada por Mill, por exemplo, para quem a tirania e as formas não democráticas de governo infligem não só a liberdade dos cidadãos, mas também sua inteligência. Dominado pela tirania, o é tratado como um incapaz, e como incapaz continua, pois "um homem teria de ter um gosto extremamente incomum pelo esforço intelectual em si e por si, para se dar ao trabalho de pensar, mesmo na certeza de que não produzirá nenhum efeito e exterior, ou para se qualificar

\footnotetext{
1 Mestre e doutorando em direito constitucional pela Universidade de São Paulo. Especialista em Direito Público e Constitucional pela Pontifícia Universidade Católica de São Paulo. Graduado em direito e filosofia. Desenvolveu pesquisa de iniciação científica e especializou-se na área de direito constitucional. Atua como advogado em São Paulo.

2 Cf. J-J ROUSSEAU. Do Contrato Social. São Paulo: Abril, 1978, p.106.

3 Cf. HOBBES, Thomas. Leviatã.. São Paulo: Abril. 1983, pp. 96 e ss.

4 Cf. MONTESQUIEU. Do Espírito das Leis. São Paulo: Abril. 1973, p. 156 e ss.

5 Cf. MILL. John Stuart. Considerações Sobre o Governo Representativo. Brasília: UNB, 1981, p.27.
}

Revista da Faculdade Mineira de Direito, v.14, n. 27, jan./jun. 2011 - ISSN 1808-9429. 
para funções que sabe não ter nenhuma chance de poder exercer". ${ }^{6} \mathrm{O}$ cidadão apático, mal informado e sem estímulo de desenvolver reflexões práticas e teóricas a respeito da vida social é resultado direto dos regimes despótico e tirânico. Nestes regimes, o ditador é onipresente e onisciente. Trata-se de um "único homem de super-humana atividade mental dirigindo todos os assuntos de um povo mentalmente passivo". ${ }^{7}$ No limite, portanto, a ditadura poda até mesmo a moral cívica da sociedade, pois, confinados à passividade e à obediência, os cidadãos não têm como desenvolver virtudes ativas, práticas e socialmente relevantes.

Contemporaneamente, John Raws sustentou em seu Uma Teoria da Justiça o mesmo raciocínio. Segundo este autor, que nesta e em outras passagens de sua obra demonstra a forte influencia que seu pensamento tem do kantismo, a moral da autoridade é a moral própria das crianças ou dos povos em fase inicial de desenvolvimento. A autoridade dos pais, no âmbito da família sobre os filhos, diz, corresponde à autoridade do ditador sobre as massas. Acrescenta, no entanto, que "a moralidade da autoridade só tem um papel restrito nas organizações sociais fundamentais, e só pode ser justificada quando exigências incomuns da atividade em questão tornam essencial que se conceda a certos indivíduos as prerrogativas da liderança e do comando. Em todos os casos, o alcance dessa moralidade é governado pelos princípios de justiça". ${ }^{8}$

O bom governo é aquele que estabelece a maior proximidade possível entre o povo e seus representantes políticos. Mas esta proximidade não pode negar a liberdade de autoderminação de qualquer destas partes. Quando este ponto é atingido, a população é politicamente ativa, os representantes são legal e politicamente legítimos e o regime político é a democracia representativa da vontade popular. Mas qual a configuração institucional que realiza este desiderato? Com certeza a negação e a difamação da representação política não realizam este fim ótimo. Um Estado em que não haja qualquer representação, um Estado onde as massas dominem o aparato administrativo e político, enfim, um Estado em que não haja qualquer resquício de representação não pode ser outra coisa que não a plena e absoluta anarquia. Seria a negação do direito. Por isso, o perigo da ditadura da maioria, que desconsidera e oprime os direitos das minorias, é um problema constante da democracia direta. ${ }^{9}$ A representação política é assim um elemento essencial da realização dos interesses

6 MILL. John Stuart. Considerações Sobre o Governo Representativo, p. 28.

7 MILL. John Stuart. Considerações Sobre o Governo Representativo, p. 28.

8 RAWS, John. Uma Teoria da justice. São Paulo. Martins Fontes: 2002, pp. 518 e 519.

9 A este respeito, os pais fundadores da democracia norte americana afirmaram claramente que "A Justiça é fim de todo governo e de toda sociedade civil: tal tem sido em todas as épocas o alvo dos esforços de todas as 
das diversas classes sociais no seio da sociedade civil. Mas não é só. É também um instrumento necessário à própria existência de um Estado democrático onde os direitos das classes minoritárias e menos favorecidas são tão valorizados quanto os interesses das classes dominantes. $^{10}$

O equilíbrio e a operacionalização do Estado Democrático de direito liberal dependem da separação nítida de Estado e sociedade Civil, representante e representado ${ }^{11}$. Só por meio da representação política freia-se tanto o poder absoluto, quanto as paixões insensatas das massas. ${ }^{12} \mathrm{O}$ estado representativo foi concebido como meio termo entre democracia e monarquia: nele relacionam-se a exigência da governabilidade administrativa e a legitimidade democrática do poder, ${ }^{13}$ nele, o poder Estatal é legítimo, nele o poder Estatal pode ser responsável frente à população, sem ser tirânico ou anárquico. Vê-se então que o conceito de representação política é central: em seu âmago encontra-se a chave para a compreensão de temas importantes para o direito, a política e a sociedade. Dentre estas possibilidades, este trabalho busca enfocar a correlação de representação e responsabilidade políticas. ${ }^{14}$

nações; e, ou a vitória tem sido o fruto de todos os seus sacrifícios, ou a liberdade tem sucumbido na luta. Tanto está em anarquia uma sociedade em que uma facção mais poderosa pode reunir-se para oprimir um partido menos poderoso, como uma horda de bárbaros ou de selvagens em que o indivíduo mais fraco não é defendido contra as injustiças do mais forte".HAMILTON, Alexander; MADISON, James; JAY, John. O Federalista. São Paulo: Abril, p. 133.

10 Karl Loewenstein foi especialmente contundente em relação a este ponto: “(...) a invenção ou descobrimento da técnica de representação foi tão decisiva para o desenvolvimento político do ocidente e do mundo, como foram para o desenvolvimento técnico da humanidade a invenção do motor a vapor, a eletricidade, o motor de explosão ou a energia atômica. Um governo é sempre indispensável para a uma sociedade estatal organizada. Mas foi a técnica da representação que tornou possível a instituição do parlamento como detentor de um poder separado e independente de governo. (...) Sem a introdução do princípio da representação, o poder político teria permanecido monolítico indefinidamente, como assim ocorreu fora do mundo ocidental até que finalmente nestes territórios o absolutismo sucumbiu ao tomar contato com a idéia do Constitucionalismo liberal’.LOEWENSTEIN, Karl. Teoria de la constitución. Barcelona: Ariel, 1965, p. 60.

11 Para uma crítica radical destas afirmações ver: MARX, Karl. A questão judaica. São Paulo: Editora Moraes. 1991, p. 26.; e Rousseau, para quem: "Desde que o serviço público deixa de constituir a atividade principal dos cidadãos e eles preferem servir com sua bolsa a servir com sua pessoa, o Estado está próximo da ruína. Se lhes for preciso combater pagarão tropas e ficarão em casa; se necessário ir ao conselho, nomearão deputados e ficarão em casa. À força de preguiça e de dinheiro, terão, por fỉm, soldados para escravizar a pátria e representantes para vende-la" (J-J ROUSSEAU. Do contrato social ou princípios do direito político. São Paulo. Abril Cultural.:1978, p. 106.

12 Cf. SCHIMITT, Carl. Théorie de la Constitution . Paris: PUF, 1993, p. 453.

13 Cf. BONAVIDES, Paulo. Ciência Política. São Paulo: Malheiros, 2006, p. 121.

$14 \mathrm{O}$ ex-Ministro do Supremo Tribunal Federal, Paulo Brossard, em obra clássica que trata do impeachment afirma, a este respeito, que: "Desde que as autoridades políticas desempenham funções, não por direito próprio, mas como agentes e servidores da nação - 'officers of the government are the trustees or servants of the people' - da qual derivam seus títulos para o exercício dos cargos políticos, seja por eleição, seja por outra forma de provimento; desde que se não admita a irresponsabilidade outrora consagrada nas antigas Monarquias, quando os grandes servidores eram antes ministros da coroa que do país, e apenas perante o rei respondiam, como este respondia somente perante Deus, único juiz a que prestava contas; desde que o povo passou a ter existência política, a disciplina da responsabilidade do governo converteu-se num dos problemas básicos da organização estatal, não tendo faltado mesmo quem visse na possibilidade de aplicar-se aos governantes o principio da responsabilidade o traço distintivo do Estado moderno". (BROSSARD, Paulo. O Impeachment, aspectos da responsabilidade do presidente da república. São Paulo. Saraiva. 1992. p. 4).

Revista da Faculdade Mineira de Direito, v.14, n. 27, jan./jun. 2011 - ISSN 1808-9429. 
A jurisprudência tem tocado neste tema. No julgamento do Mandato de Segurança 20.927/DF questionou-se a possibilidade de suplente, que havia trocado de partido antes de tomar posse de mandato parlamentar na Câmara dos Deputados Federal, perder o direito de ser empossado tendo em vista a infidelidade partidária caracterizada em seus atos. Tratava-se do segundo suplente, deputado Marcos César Formiga Ramos, eleito pelo Partido da Frente liberal, que, antes de tomar posse, filiou-se ao Partido Liberal. O mandato de segurança foi impetrado pelo terceiro suplente, que almejava suceder o "tranfuga" caso este fosse punido com a perda do mandato pela infidelidade partidária. Prevaleceu, no caso, o posicionamento adotado pelo Ministro Moreira Alves, para quem a Constituição não estabelece a perda de mandato para o Deputado que, eleito pelo sistema de representação proporcional, muda de Partido.

Esta interpretação tem fundamentos históricos muito fortes, que foram por diversas vezes considerados pelos Ministros do Supremo Tribunal Federal neste julgamento. Os Ministros Nery da Silveira, Moreira Alves e Aldir Passarinho foram enfáticos ao afirmar que a nova Constituição não repetiu a regra existente sob a égide da Constituição de 1967, reformada pela emenda Constitucional de 1969. ${ }^{15}$ A emenda Constitucional 25 de 1985 extinguiu esta possibilidade. A nova ordem constitucional seguiu o mesmo caminho. Disso deriva a dificuldade em admitir a possibilidade de perda de mandato do trânsfuga: a Constituição teria aqui silenciado eloqüentemente. Este é o argumento fundamental de toda a discussão acerca da perda de mandatos parlamentares por infidelidade partidária. Ainda hoje, o argumento é influente. Em recentes demandas que envolveram a constitucionalidade de parecer em consulta formulado pelo Superior Tribunal Eleitoral ${ }^{16}$, o Procurador Geral da República, Antônio Fernando de Sousa, valeu-se exatamente deste argumento para emitir parecer contrário à possibilidade de o Supremo dar interpretação ampliativa ao disposto no art. 55 da Constituição Federal. ${ }^{17}$ Este entendimento também foi seguido pelos Ministros Eros Grau e Joaquim Barbosa.

15 O art. 152 estatuía que: "Perderá o mandato no Senado Federal, na Câmara dos Deputados, nas Assembléias Legislativas e nas Câmara Municipais quem, por atitudes ou pelo voto, se opuser às diretrizes legitimamente estabelecidas pelos órgãos de direção partidária ou deixar o partido sob cuja legenda foi eleito. A perda do mandato será decretada pela Justiça Eleitoral, mediante representação do partido, assegurado o direito de ampla defesa".

16 Trata-se da consulta 1.398/DF ajuizada pelo Partido da Frente Liberal.

17 Segundo Antonio Fernando, a Constituição Federal tem, em seu artigo 55, um rol taxativo de hipóteses de perda de mandato, e a troca de partido não está incluída. Outro dispositivo constitucional (parágrafo $1^{\circ}$, do artigo 17) diz que cabe aos partidos estabelecer normas de fidelidade partidária em seus estatutos, o que não ocorre no caso do DEM, do PSDB e do PPS. Em outras palavras, para o procurador-geral, a Constituição Federal não autoriza a perda de mandato parlamentar por infidelidade partidária. Para ele, o entendimento do Tribunal Superior Eleitoral (TSE) segundo o qual o mandato pertence ao partido é limitado e não resolve a 
De outro lado, o Ministro Celso de Mello acompanhou a divergência firmemente defendida na matéria pelo Ministro Paulo Brossard. Os motivos apresentados por estes Ministros foram diversos. Enquanto o Ministro Celso de Mello entendeu, tal qual a maioria, que as causas de perda de mandato parlamentar foram taxativamente elencadas pelo art. 55 da Constituição Federal, ressaltando, no entanto, que esta prerrogativa constitucional não era extensível ao suplente que nem mesmo havia tomado posse de seu mandato, o Ministro Brossard, entendeu que o mandato parlamentar, por força do sistema de eleição proporcional, pertence ao partido, pelo que, o deputado que não atender ao imperativo da fidelidade partidária deve ser punido com a perda do mandato parlamentar. Hoje este é o entendimento prevalente. Tal qual pressagiou o Ministro Brossard, entende a atual composição do Supremo que o mandato parlamentar traz consigo imperativos e responsabilidades de natureza legal e moral. O mandatário tem responsabilidades não só para com o para com o partido que o elegeu, mas também frente ao povo que confiou votos no candidato e na ideologia que ele até então defendeu. O Ministro Paulo Brossard falava de respeito aos compromissos e honestidade do parlamentar, hoje o discurso dos Ministros Celso de Mello do Supremo Tribunal Federal e Cesar Asfor Rocha do Superior Tribunal de Justiça fala em moralidade, responsividade e responsabilidade dos mandatários do povo. Segundo o voto deste último Ministro na Consulta 1.398/DF, formulada pelo Partido da Frente Liberal, “(...) razões de ordem jurídica e, sobretudo, razões de ordem moral, inquinam a higidez dessa movimentação (mudança de partidos por representantes eleitos), a que a Justiça Eleitoras não pode dar abono, se instada a se manifestar a respeito da legitimidade de absorção do mandato eletivo por outra corrente partidária, que não recebeu sufrágios populares para o preenchimento daquela vaga". No mesmo sentido, ao julgar o Mandado de Segurança de n. 26603/DF, o Ministro Celso de Mello fez longa referência aos valores morais e sociais que constringem o representante político. A liberdade destes atores políticos, segundo a formulação deste Ministro, não abrange a possibilidade de mudar de partidos e ideologias ao seu bel prazer. Há que se respeitar, nestes casos, a vontade popular. Há que se ter assim responsabilidade eleitoral.

\footnotetext{
“síndrome crônica que acomete o sistema político-partidário no Brasil”.Para Antonio Fernando, esse impasse tem de ser solucionado por meio de uma reforma política ampla, que institua uma fidelidade ao eleitor, e não só uma fidelidade partidária. "O Ministério Público não desconhece que, do ponto de vista ético e político, a solução formulada pelo TSE é razoável. Mas, por outro lado, não pode defender providência que a Constituição não diz ou determina." Antonio Fernando alega que "são ética e politicamente reprováveis" tanto a troca de partido por parlamentar quanto ao desvio partidário, quando a legenda faz acordos incompatíveis com seu programa político e com seu discurso eleitoral. "A diferença é apenas uma, mas substancialmente relevante: na desfiliação partidária, o ato de infidelidade ao eleitor é individual, enquanto que, no desvio partidário, o ato é coletivo."
} 
É preciso observar criticamente este posicionamento. Sua conclusão ataca frontalmente uma premissa fundamental da ordem constitucional: a liberdade de convicção política do parlamentar. ${ }^{18}$ Dizer que o mandato parlamentar é uma das instituições fundamentais da democracia, mas negar a liberdade de seu exercício é uma contradição de difícil assimilação lógica e jurídica. Se sua existência e exercício deveriam ser preservados a qualquer custo, por que condicioná-lo ao cumprimento de determinações partidárias, sendo que a prática tem confirmado a parcialidade destas diretrizes? A democracia representativa realiza-se por meio do mandato parlamentar. No entanto, a possibilidade de serem extintos mandatos por infidelidade partidária abre o caminho para a perseguição política. É perfeitamente possível cogitar que divergências internas ao partido que culminem na perseguição alguns deputados, ou membros com visão minoritária. Que fazer nestes casos? O Ministro Cesar Peluso apresentou solução engenhosa para estes casos. Segundo seu entendimento, expresso no voto de sua autoria na Consulta 1.398/DF, o mandato eletivo do parlamentar que troque de legenda durante o exercício do mandato permanecerá com o partido. Há, no entanto, importantes exceções a essa regra geral, são elas: a existência de mudança significativa de orientação programática do partido, e a comprovada perseguição política dentro do partido que abandonou. ${ }^{19}$ Com este fundamento, o Tribunal Superior Eleitoral elaborou Resolução que disciplina o procedimento de perda de mandato do deputado infiel. $^{20}$

A solução é engenhosa, mas insatisfatória. Questões jurídicas intrincadas, envolvendo a separação de poderes e a legitimidade do judiciário, podem surgir daí. Como seria possível afinal ao judiciário avaliar se houve ou não perseguição política? A própria natureza

\footnotetext{
18 Neste sentido é preciso citar as palavras da professora Mônica Herman Salen Caggiano: "Há, de outra parte, todo o arcabouço principiológico, com status constitucional a tutelar a figura do candidato, assegurando-lhe um estatuto comandado pela idéia de liberdade, como anteriormente apontado. E, em razão dessa rede protetora de nível constitucional, não nos parece possa o legislador infraconstitucional impor óbices ao exercício do direito de postular cargos eletivos, criando hipóteses de inelegibilidade não sustentadas pela Lei Maior, ou o interprete a promover exercícios de hermenêutica a flexibilizar a natureza do mandato representativo estabelecida pelo constituinte". (CAGGIANO, Mônica Herman Salen. A Fenomenologia dos trânsfugas no cenário político-eleitoral brasileiro, in 'O voto nas Américas', coord. Cláudio Lembo, org. Monica Herman Caggiano, Barueri, Minha Editora, 2008, p. 252)

19 Esta diretriz foi positivada na Resolução 22.610/07 do TSE.

20 O Tribunal Superior Eleitoral editou a Resolução-TSE n 22.610, de 25.10.2007, alterada pela Resolução$\operatorname{TSE}^{\circ}{ }^{2} 2.733$, de 11.03.2008, que disciplina o processo de perda de cargo eletivo e justificação de desfiliação partidária.De acordo com a Resolução, o partido político interessado pode pedir, perante a Justiça Eleitoral, a decretação da perda de cargo eletivo em decorrência de desfiliação partidária sem justa causa. Conforme $\S 1^{\circ}$, do art. $1^{\circ}$, considera-se justa causa a incorporação ou fusão do partido, a criação de novo partido, a mudança substancial ou desvio reiterado do programa partidário e grave discriminação pessoal. Podem formular o pedido de decretação de perda do cargo eletivo o partido interessado, o Ministério Público Eleitoral e aqueles que tiverem interesse jurídico, de acordo com a norma. O TSE é competente para processar e julgar pedido relativo a mandato federal. Nos demais casos, é competente o Tribunal Eleitoral do respectivo estado.
}

Revista da Faculdade Mineira de Direito, v.14, n. 27, jan./jun. 2011 - ISSN 1808-9429. 
eminentemente política da atuação parlamentar depõe contra esta possibilidade: afinal as ideologias partidárias são na maioria das vezes fluídas e indiferenciadas, o que encontra explicação na sociologia dos partidos políticos. ${ }^{21}$ Mais: frente à garantia constitucional de liberdade de palavras e votos e opiniões atribuída aos parlamentares, é difícil imaginar a ingerência do judiciário no âmbito de suas convicções. Mas é perfeitamente possível que a controvérsia intra-partidária tenha justamente como objeto este âmbito de atuação parlamentar, que a Constituição protege de forma quase que absoluta. Há alguns anos, deputados do partido dos trabalhadores divergiram da cúpula partidária no que respeita a uma das propostas de reforma da previdência social, entre outros temas. O caso é importante para a discussão vez que a minoria dos deputados e Senadores que se posicionaram em desfavor da alteração constitucional nada mais faziam que seguir a diretriz do programa partidário. ${ }^{22}$ Seria então este um caso em que se justifica a perda do mandato? Ou seria o caso de legitimar a mudança de partido tendo em vista a alteração do conteúdo programático-ideológico defendido pelo partido? É possível que o Judiciário resolva, com base nos argumentos sustentados pelo Ministro Cesar Peluso, questões intrincadas como esta. No entanto, é provável que este julgamento implique em violação tão grave à natureza e ao funcionamento do mandato representativo, quanto seria a própria mudança partidária do deputado julgado como infiel. Ou seja, neste caso o remédio parece ser mais nocivo que a própria doença. ${ }^{23}$

21 MICHELS, Robert. Sociologia dos Partidos Políticos, Brasília: UnB, 1982

22 O ápice deste caso envolveu o embate da senadora Heloisa Elena com a cúpula do Partido dos Trabalhadores, então titularizada por José Genuíno. A senadora Heloísa Helena (AL) tem uma história de forte oposição ao governo, mesmo antes de o presidente Lula tomar posse e definir a equipe ministerial. Em dezembro do ano passado, a senadora criticou fortemente a indicação de Henrique Meirelles para a presidência do Banco Central e não participou da sabatina dele no Senado. "É uma personalidade (Meirelles) que, ao longo de sua história, serviu aos interesses financeiros internacionais. Não serve aos interesses nacionais", afirmou na época. Heloísa Helena também boicotou a eleição de José Sarney (PMDB-AP) para a presidência do Senado Federal, afirmando que o ex-presidente representava o continuísmo das oligarquias no poder. Em abril deste ano a senadora ameaçou ir à Justiça contra as propagandas preparadas pelo governo para explicar as reformas da Previdência e tributária, mas voltou atrás na decisão. Helena cobrou ainda um debate sobre a elevação dos juros básicos da economia e a respeito da possibilidade de aumento da meta de superávit primário e defendeu também a união do PT contra o projeto que prevê a autonomia operacional do Banco Central, a flexibilização das leis trabalhistas e uma reforma da Previdência que seja contrária ao discurso do partido. "Essa é uma temática cara para o PT. Recordemos os nossos discursos na campanha e na oposição ao governo FHC para que façamos um debate qualificado na sociedade", afirmou. Com o afastamento da bancada do PT no Senado, Heloísa Helena não poderá falar pelo partido no plenário e não participará das reuniões da bancada. O Conselho de Ética do Diretório Nacional do PT deverá votar em breve a expulsão da senadora do partido. Heloísa afirmou que vai recorrer da decisão.

23 Para se compreender plenamente o problema, deve-se ter em conta que a liberdade parlamentar consiste em princípio fundamental de toda ordem constitucional que vise assegurar a separação e harmonia dos poderes. Neste sentido, a Constituição brasileira, seguindo a tradição do constitucionalismo europeu, dá efetividade à liberdade parlamentar por meio de dois instrumentos: a imunidade material (art. 53, caput da Constituição Federal Brasileira), que é a imunidade de pensamento e expressão; e a imunidade formal (art. 53, $\$ 2^{\circ}$, com redação dada pela Emenda Constitucional $n^{\circ} 35$ ) que protege, desde a expedição do diploma, a liberdade de ir e vir dos deputados e senadores. A importância destes institutos é devidamente salientada por Fernanda Dias Meneses de Almeida: "Na espécie, o juridicamente protegido é da instituição legislativa ou, antes ainda, do

Revista da Faculdade Mineira de Direito, v.14, n. 27, jan./jun. 2011 - ISSN 1808-9429. 
No plano teórico definiam-se doutrinas que buscam enfrentar este tipo de problemática. Há quem pregue uma grande reformulação da sistemática da representação política. Há ainda os que pregam ser necessária maior participação direta do eleitorado na política nacional, o que se daria por meio dos institutos do referendo, plebiscito e iniciativa de lei. ${ }^{24}$ Todas são propostas importantes para o desenvolvimento da democracia nacional. Importa, no entanto, ter em conta que o Parlamento e seus integrantes também têm grande valor para a democracia e que a desmoralização deles não contribui em nada para a democracia. É, pelo contrário, contrária a ela. É preciso buscar um ponto de equilíbrio, mesmo que tenso, entre democracia e representatividade. A vontade do povo é realizada por e pelos representantes políticos, mas não ao ponto de anular a convicção moral e racional destes. Seguir a linha proposta hoje pelos tribunais superiores é seguir nesta eterna linha de eterna tensão.

\section{VINCULAÇÃO E DESVINCULAÇÃO DO MANDATO PARLAMENTAR}

Representar é tornar presente o ausente. Trata-se de uma operação de natureza intelectual, que pode ser feita tanto por meio de conceitos quanto por entes concretos. Diz-se, assim que um mapa representa o planeta terra, mas também que a foto representa a paisagem ou que a virtude representa um ideal de vida. Todos esses elementos fazem presente algo, um objeto que está ausente. ${ }^{25} \mathrm{O}$ aspecto político da representação, a representação política, nasceu na modernidade. Contestada e combatida por muitos, exaltada e defendida por outros, a necessidade e a regulamentação da representação política sempre gerou problemas práticos e teóricos do ponto de vista da teoria democrática. Rousseau foi quem demonstrou com mais eloquiência os problemas gerados pela representação de interesses na democracia. Sua posição

povo, que quer sua representação respeitada. Para possibilitar o exercício das funções do mandato é que se conferem imunidades aos parlamentares. São estas, pois, inequivocamente, prerrogativas funcionais outorgadas aos representantes do povo, nesta condição" (ALMEIDA, Fernanda Dias Menezes. Imunidades Parlamentares. Brasília, Câmara dos deputados, 1982, p. 61).

24 Fora o caso do desmembramento e incorporação de estados (art. 18, $\S 3^{\circ}, \mathrm{CF}$ ), as consultas populares são de execução voluntária. Por isso, a fórmula encontrada pela Lei 9.709/98 para convocar plebiscitos e referendos é, no mínimo, contraditória. O art. $3^{\circ}$ deste diploma legal dispõe que "o plebiscito e o referendo são convocados mediante decreto legislativo, por proposta de um terço, no mínimo, dos membros que compõem qualquer das Casas do Congresso Nacional, de conformidade com esta Lei". Com isso, a competência de convocar plebiscitos e referendos foi conferida justamente ao órgão a quem estes institutos menos interessa: o Congresso nacional. Por que, deve-se perguntar, o Congresso convocaria plebiscitos ou referendos se estes institutos retiram sua competência? Dada tal regulamentação, é deveras improvável que o Congresso convoque plebiscitos ou referendos, o que se comprova na prática: após 20 anos de vigência da constituição de 1988 o Congresso nacional convocou tão somente um plebiscito. Ao que parece, portanto, o art. 14, caput, in fine, da $\mathrm{CF}$, tem hoje pouca ou nenhuma efetividade, o que poderia ser discutido até mesmo em ação direta de inconstitucionalidade por omissão parcial.

25 Neste sentido: SILVA, Virgílio Afonso da. Sistemas Eleitorais, tipos efeitos jurídico-políticos e aplicação ao caso brasileiro, São Paulo, Malheiros, 1999. 
crítica em relação à representação política é tão conhecida quanto mal compreendida. Subjaz à crítica formulada por Rousseau à representação política a identificação de uma reminiscência do cristianismo feudal neste conceito político. Rousseau afirma que a representação teve origem nos governos feudais: foi com base nas doutrinas cristãs da representação de Deus na pessoa do monarca que o feudalismo nasceu, cresceu e se solidificou como doutrina política e social prevalente na Europa. Combater o feudalismo é assim, para Rousseau, combater a representação política. Neste sentido, chega a afirmar que ela é fonte de toda iniqüidade e servidão. ${ }^{26}$

Já autores como Edmund Burke e Montesquieu, por exemplo, que entendem que o Parlamento representa dois entes abstratos que, no fundo, se confundem: a razão e a nação. Esta é definida como a comunidade cultural que une o povo, suas gerações futuras e passadas. $^{27}$ Desta forma, os interesses momentâneos de grupos sociais, ou mesmo da sociedade como um todo, não podem e não devem determinar o entendimento e o posicionamento do legislador sobre dada matéria. ${ }^{28}$ Estes atores demonstram quão próximos estão os conceitos de nação, totalidade e razão e como a conjunção de todos eles fundamenta a compreensão da função legislativa enquanto órgão autônomo. Os interesses deste são tidos como parciais e hostis entre si; já a consideração racional e total do parlamentar identifica-se ao bem comum, sempre constante e imutável. ${ }^{29}$ Por isso o corpo legislativo pode, deve em

26 John Stuart Mill chegou a conclusão semelhante, considerando que: "Não há nenhuma dificuldade em demonstrar que a forma ideal de governo é aquela em que a soberania, o poder supremo em última instância, pertence à massa reunida da comunidade; aquela em que todo cidadão não apenas tem uma voz no poder supremo, mas também é chamado, pelo menos ocasionalmente, a tomar parte ativa no governo pelo exercício de alguma função pública, local ou geral”.26 Mas, adicionava Mill: “(...) como, nas comunidades que excedem as proporções de um pequeno vilarejo, é impossível a participação pessoal de todos, a não ser numa porção muito pequena dos negócios públicos, o tipo ideal de um governo perfeito só pode ser o representativo". (MILL. John Stuart. Considerações Sobre o Governo Representativo. Brasilia: UNB. p. 38).

27 Cf. FERREIRA FILHO, Manuel Gonçalves. Do Processo Legislativo. São Paulo: Saraiva. 2003. p. 107. Também neste sentido: BONAVIDES, Paulo. Ciência Política. São Paulo: Malheiros. p. 228.

28 Claramente Burke expõe este ponto no seu famoso Discurso aos eleitores de Bristol: "El Parlamento no es un congreso de embajadores que defienden intereses distintos y hostiles, intereses que cada uno de sus miembros debe sostener, como agente y abogado, contra otros agentes y abogados, sino una asamblea deliberante de una nación, con un interés: el de la totalidad; donde deben guiar no los intereses y prejuicios locales, sino el bien general que resulta de la razón general del todo". (BURKE, Edmund. Textos Políticos. México, Fondo de Cultura Econômica, 1996, p, 313).

29 Autores do século XVII como John Milton assumiram posicionamento semelhante. A experiência das guerras civis inglesas, o racha do parlamento e a ditadura de Cromwell foram fatos históricos que influenciaram em muito o pensamento destes autores. O fundamento moral e cívico que estes autores identificam na soberania passa a ser então um fator preponderante na identificação da legitimidade dos órgãos estatais. Sendo assim, argumentou Milton: "E se a maioria do Parlamento preferisse se tornar escrava e por a república à venda - não deveria se permitir que a minoria impedisse isso e conservasse sua liberdade, se isso está em seu poder?" (MILTON, John. Escritos políticos, "A defesa do povo inglês". São Paulo, Martins Fontes, 2005, p. 239). Desta forma, mesmo o parlamento, que, para estes autores é o órgão que, por excelência, representa os interesses do povo, se tornará ilegítimo e tirânico quando agir sem considerar o bem comum e os interesses da nação como um todo. $\mathrm{O}$ mesmo argumento foi repedido à exaustão pelos pais fundadores da América em $\mathrm{O}$ Federalista. 
algumas circunstâncias, tomar posições políticas impopulares e contrárias ao interesse popular, sem que isso implique em degeneração do mandato representativo. Neste sentido a representação assume um significado especifico e técnico: diz-se que o deputado representa o corpo eleitoral que o elegeu não no sentido de comungar das mesmas intenções, ideologias ou características culturais. Nem mesmo há representação no sentido de o deputado ser responsável por seus atos frente aos representados. Há, isso sim, representação no sentido de que ele, o deputado representante, representa no sentido de substituir, no sentido do tomar o lugar de alguém - no caso o representado - o que faz em razão de qualidades cívicas e teóricas que lhe são próprias. ${ }^{30}$ Esta é a teoria do mandato representação.

Foi esta a visão de representatividade que, por influência do Abade Sieyès, imperou na assembléia constituinte que aprovou a primeira Constituição Francesa de 3 de setembro de 1791 em cujo artigo $7^{\circ}$ ficou consignado: “Os representantes designados nos departamentos não serão representantes de um departamento particular, mas da não inteira e nenhum mandato lhes poderá ser dado". ${ }^{31} \mathrm{O}$ Estatuto Fundamental Italiano de 1848 tratou o tema nos mesmos termos ao dispor que "Os deputados representam a nação em geral, e não apenas as províncias pelas quais foram eleitos” (art. 41), ao passo que a Constituição Alemã de 1919 foi ainda mais enfática estabelecendo em seu artigo 21 que "Os deputados são os representantes de todo o povo, não obedecem senão a sua consciência e não se acham presos a nenhum mandato". Mas, com o século XX vieram a industrialização e o Estado Social, fenômenos que colocaram em xeque a doutrina do mandato representativo. O conflito de classes, os interesses econômicos, os grupos sindicais que emergiam da nova ordem social refletiam seus interesses parciais no Parlamento. ${ }^{32}$ Seus membros deixaram então de pautar sua conduta por regras gerais e passaram a defender os interesses particulares dos grupos econômicos a que estavam vinculados. Deixavam, com isso, de buscar e defender o bem comum da sociedade. Passaram a ser meros representantes de interesses, influenciáveis por grupos de pressão e lobbies institucionais. $^{33}$

A crescente profissionalização da atividade parlamentar é sintoma deste fato. Ao contrário do representante político do século XVIII, que exercia a função parlamentar pela honradez do cargo, o político do século XX fez da legislatura um modo de vida, ficando assim

\footnotetext{
30 “A essência da representação é que as pessoas desvinculam-se de seu poder, e o concedem, por um período limitado, ao deputado por elas escolhido, e que este deputado deve desempenhar no governo aquele papel que, se não fosse a transferência, seria desempenhado pelas próprias pessoas. Não há representação se os constituintes agirem por si mesmos". (Gil, Maria D’Alva. Representação política e sistema eleitoral no Brasil, São Paulo, Edições Símbolo, 1980, p. 30).

31 Titulo III. Capítulo I. Secção III. Artigo $7^{\circ}$.

32 Cf. FERREIRA FILHO, Manoel Gonçalves. Do processo legislativo, p. 121
}

Revista da Faculdade Mineira de Direito, v.14, n. 27, jan./jun. 2011 - ISSN 1808-9429. 
muito mais sucessível a apelos de grupos de pressão econômicos. ${ }^{34}$ Por paradoxal que seja, o lobby ${ }^{35}$ tornou-se então instituição permanente no Estado cujo Parlamento foi louvado por Madison como a "casa dos sábios". ${ }^{36}$ Fatos políticos e econômicos também desmentiam a doutrina jurídica do mandato representativo. ${ }^{37}$ Havia, obviamente, uma relação estreita entre o parlamentar e os grupos sociais que o apoiavam. Isto levou ao ressurgimento da doutrina do mandato imperativo ${ }^{38}$ que se caracteriza pela equiparação do mandato político àquele disciplinado pelo direito civil. Neste sentido, a relação representado-representante como uma espécie da relação mandante-mandatário, condicionando completamente a atuação parlamentar aos interesses daqueles que o elegeram.

Nesta linha, Kelsen foi um dos autores que lançaram duras críticas à teoria do mandato representativo. ${ }^{39}$ Por outro lado, Norberto Bobbio salientou, em defesa do mandato representativo, que o mandato imperativo era característica do Estado autocrático. ${ }^{40} \mathrm{Já}_{\text {Sartori }}$ e Duguit não sustentam que a opção pelo mandato imperativo ${ }^{41}$ importa na extinção do

33 Cf. BONAVIDES, Paulo. Ciência Política, p. 231.

34 Cf. FERREIRA FILHO, Manoel Gonçalves. Do processo legislativo, pp. 94 a 109.

35 Federal Regulation os Lobbying Act, 1946, USA.. No Brasil o PL. 5470/2005 em tramite na Câmara dos Deputados define "lobby" como: "lobby" ou pressão, o esforço deliberado para influenciar a decisão administrativa ou legislativa em determinado sentido, favorável à entidade representativa de grupo de interesse, ou de alguém atuando em defesa de interesse próprio ou de terceiros, ou em sentido contrário ao interesse de terceiros; (art. $\left.2^{\circ}, \mathrm{VI}\right)$

36 HAMILTON, Alexander; MADISON, James; JAY, John. O Federalista. São Paulo. Abril. p. 99.

37 Para Celso Fernandes Campilongo esta é a principal razão da crise instaurada sobre o conceito de representação política: “A crise da representação política reflete, na verdade, um desajuste entre as formas políticas e as formas econômicas. Paralelamente à crise das instituições políticas desenvolve-se a crise das formas de trabalho, da organização do ciclo econômico, do papel do Estado no sistema produtivo, etc. Através dessa fenda, ressaltando a reciprocidade entre forma política e forma econômica, a crise da representação pode ser estudada em três dimensões: a crise dos partidos, a irrupção dos movimentos sociais e o neocorporativismo". CAMPILONGO, Celso Fernandes. Representação política e ordem jurídica: os dilemas da democracia liberal. Tese de mestrado apresentada no departamento de Teoria Geral do Direito da Faculdade de Direito da Universidade de São Paulo. Orientador: Professor José Eduardo Campos de Oliveira. 1987. p. 96.

38 A este respeito, Sr. Courtenay Ilbert salienta que: "Los Parlamentos eran cortos. Los miembros tenían que residir en sus distritos parlamentarios. Recibían de sus electores dietas para gastos. Corporaciones y comunidades subvencionaban a los agentes y delegados". ILBERT, Courtenay Peregrine. El Parlamento su historia, constitución y practica. Buenos Aires. Labor. 1930. p. 135.

39 Afirmou enfaticamente que: "Se os autores políticos insistem em caracterizar o parlamento da democracia moderna, a despeito de sua independência do eleitorado, como um órgão representativo, eles não apresentam uma teoria cientifica, mas advogam uma ideologia política. A função desta ideologia é dissimular a situação real, é sustentar a ilusão de que o legislador é o povo, apesar do fato de que o legislador é o povo, apesar do fato de que, na realidade, a função do povo - ou formulado mais corretamente do eleitorado - limita-se à criação do órgão legislativo". (KELSEN, Hans. Teoria Geral do direito e do Estado. 3. ed. São Paulo. Martins Fontes. 2000. p. 416).

40 "Quem age à base de instruções rígidas é o porta-voz, o núncio, nas relações internacionais o embaixador; a rigidez das instruções não é exatamente um modo característico do agir dos corpos coletivos. É uma característicos dos organismos regulados por critérios hierárquicos, isto é, daqueles organismos nos quais o fluxo de poder precede do alto para baixo e não de baixo para cima, e é portanto muito mais adequada aos sistemas autocráticos que aos sistemas democráticos" (BOBBIO, Norberto. O futuro da Democracia. São Paulo. Paz e Terra. 2004. p. 64).

41 Cf. SARTORI, Giovani. Teoria da Representação (...) p. 78 a 86.

Revista da Faculdade Mineira de Direito, v.14, n. 27, jan./jun. 2011 - ISSN 1808-9429. 
próprio Estado de Direito. Para estes autores não se pode desprezar o fato de o Parlamento ser um órgão Estatal, a despeito da proximidade que o mesmo deve ter com o corpo eleitoral. Assim, mesmo que se admita que os parlamentares sofram importantes influências dos grupos sociais a que se vinculam, deve-se considerar que eles são funcionários (fonctionnaires) ${ }^{42}$ de um órgão de Estado, o Parlamento, que adquire seus poderes da nação que o elegeu. ${ }^{43} \mathrm{Com}$ o fim de garantir a identidade entre representante e representado, estes autores apelam a vínculos de solidariedade social (solidarité sociale) ${ }^{44}$ e de natureza ética entre mandatários e mandantes. Haveria elementos morais e éticos que aproximam o parlamentar da população, conferindo, assim, legitimidade ao parlamento e a seus ocupantes. ${ }^{45}$ Já Maurice Duverger ${ }^{46} \mathrm{e}$ Canotilho $^{47}$ levam a discussão para campo diverso. Estes autores argumentam que, com a criação de partidos políticos organizados, cuja função é condensar a opinião pública sob bases ideologicamente organizadas, a oposição entre mandato imperativo e representativo perdeu todo sentido. ${ }^{48}$

Com visão semelhante a estes últimos autores, o Supremo Tribunal Federal julgou na Ação Direta de Inconstitucionalidade $n^{\circ}$ 1.351/DF inconstitucionais diversos dispositivos da Lei dos Partidos políticos - Lei 9.096/95. As normas impugnadas ${ }^{49}$ estabeleciam o que se convencionou chamar de 'cláusula de desempenho partidário'. ${ }^{50}$ Os Ministros do Supremo consideraram que a diversidade ideológica representada por partidos que seriam afetados pela

42 Cf. DUGUIT, Leon. Traité du Droit Constitutionel. Paris. BOCCARD. 1928. V. 2. p . 654.

43 Cf. DUGUIT, Leon. Traité du Droit Constitutionel (...) p. 645.

44 Cf. DUGUIT, Leon. Traité du Droit Constitutionel (...) p. 639.

45 Cf. SARTORI, Giovani. Teoria da Representação (...) p. 82.

46 DUVERGER, Maurice. Os Partidos Políticos. Rio de Janeiro. Zahar. 1970. p. 402.

47 CANOTILHO, José Joaquim Gomes. Direito Constitucional. Coimbra. Almeida. 1993. p. 733

48 Neste sentido afirma Canotilho: “A compreensão jurídico constitucional da representação parlamentar não se reconduz ao modelo representativo liberal. A relação deputado-eleitores é hoje substituída por uma referencia triangular onde converge relação entre os eleitores e os partidos e a relação entre os partidos e os deputados, além da relação eleitores-representantes".(CANOTILHO, José Joaquim Gomes. Direito Constitucional. Coimbra. Almeida. 1993. p. 733).

49 Art. 13. Tem direito a funcionamento parlamentar, em todas as Casas Legislativas para as quais tenha elegido representante, o partido que, em cada eleição para a Câmara dos Deputados, obtenha o apoio de, no mínimo, cinco por cento dos votos apurados, não computados os brancos e os nulos, distribuídos em, pelo menos, um terço dos Estados, com um mínimo de dois por cento do total de cada um deles.

50 O resumo elaborado pelo Ministro Gilmar Mendes em seu voto é elucidativo, diz ele que "o partido político que não obtiver tais percentuais de votação não terá direito ao funcionamento parlamentar, o que significa a não-formação de bancadas e de suas lideranças, com todas as repercussões que isso pode causar, como a nãoparticipação em comissões parlamentares e o não-exercício de cargos e funções nas casas legislativas. Além disso, o partido somente terá direito a (a) receber $1 \%$ (um por cento) do Fundo Partidário (art. 41, II); e (b) à realização de um programa em cadeia nacional, em cada semestre, com a duração de apenas 2 (dois) minutos (art. 48). Esses são os contornos normativos da denominada cláusula de barreira instituída pelo art. 13 da Lei n 9.096/95”. Voto Gilmar Mendes, ADI 1351/DF. 
cláusula de desempenho e a importância destes agrupamentos partidários na democracia representativa são fatores impeditivos à aplicação da cláusula de desempenho. ${ }^{51}$

É preciso observar, no entanto, que as diversas posições acerca da natureza, limites e responsabilidades inerentes ao mandato parlamentar não são de todo excludentes. Elas se mesclam no intento de, ao mesmo tempo, preservar a integridade da função parlamentar conferindo assim liberdade de convicção ao representante - e conferir representatividade ao seu exercício. Os votos e as discussões trazidas pelo Supremo Tribunal Federal no julgamento acima demonstram a preocupação dos Ministros em conciliar a representatividade das minorias no parlamento e, ao mesmo tempo, credenciar a independência dos parlamentares. Em certo sentido, viu-se então que estes valores colidem. No entanto, a trilha aberta por julgamentos como este, ou o entendimento tomado pelo Superior Tribunal Eleitoral quanto à questão da fidelidade partidária, demonstram que o atual estágio legislativo e jurisprudencial tende a valorizar, prioritariamente, a ética, a moral e os valores fundamentais da cidadania, o que, muitas vezes, implica em limitar o direito pleiteado por maiorias e grupos poderosos de poder. Parece ser possível concluir disso que o Supremo define de mais a mais e em detrimento do Parlamento os rumos da democracia brasileira.

\section{CONCLUSÃO}

Este trabalho delineou os principais aspectos teóricos e práticos relacionados aos conceitos clássicos de representatividade parlamentar, mandato representativo e mandato imperativo. Buscou demonstrar também que tais conceitos funcionam como fundamento interpretativo da ordem constitucional republicana e democrática - este caminho argumentativo foi trilhado com o objetivo de elucidar as principais discussões e tensões políticas e jurídicas relacionadas à independência do mandatário político. Ressaltou-se, neste sentido, que a partir da interpretação destes conceitos podem ser analisadas questões relevantes relacionadas à independência e liberdade do Parlamento, dos parlamentares, assim como à responsabilidade destes órgãos e funcionários. Este percurso demonstrou que a representatividade dos representantes políticos muitas vezes sustenta sua liberdade, mas casos há em que se chocam a liberdade do representante e a do próprio Parlamento. São paradigmáticas a este respeito as decisões jurisdicionais ligadas à extinção do mandato parlamentar por infidelidade partidária e à prerrogativa de partidos minoritários terem atuação

51 Neste sentido lê-se no voto do Ministro Gilmar Mendes que: “(...) se os partidos políticos estabelecem a mediação entre o povo e o Estado, na medida em que apresentam lideranças pessoais e programas para a 
parlamentar assegurada demonstram esta tendência. Todavia, estas mesmas decisões demonstram quão tênue é a linha divisória que separa as atuações política e jurídica do judiciário: ao arrogar para si a competência da definição de conceitos estritamente políticos envolvendo as diretrizes ideológicas dos partidos políticos, o Supremo Tribunal Federal deixa de exercer a competência que lhe é própria, o guardião da Constituição, para tornar-se o guardião da moralidade política e das diretrizes partidárias. Por perturbadora que possa ser, a única conclusão realista a que pode chegar este trabalho é bastante cética no que diz respeito a este empreendimento ativista do Supremo: falta a este órgão tomar consciência das reais complexidades do procedimento democrático e de suas condições. O Supremo não é, não pode ser, nem será o salvador de todos os males da democracia brasileira. $\mathrm{Na}$ verdade, decisões como as aqui analisadas evindeciam justamente o contrário: ao interferir severamente na definição de temas importantes do processo democrático, o Supremo não consegue impedir a realização de acertos político-eleitorais que são característicos do Brasil. Basta observar que, mesmo depois das decisões, auto proclamadas pelo Supremo como moralizantes do processo eleitoral, o jogo democrático continua o mesmo: realizam-se amplas alianças eleitorais, os programas partidários são indistintos, as campanhas são centradas em personalidades e pessoas, não idéias e, acima de tudo, o representante continua distante do eleitorado. Estes pontos fundamentais do sistema político não foram minimamente alterados pelo Supremo. Mas o que importa constatar é que não serão, a não ser que o órgão superior do judiciário se considere órgão superior da e à Constituição. Tomar consciência deste fato seria importante ao menos para que a discussão de propostas no sentido do aprimoramento do sistema político partidário brasileiro se desse no âmbito que lhe é natural: a esfera política.

\begin{abstract}
This paper aims to discuss and analyze the fundamental characteristics of the legal system undergoing parliamentary holders. Thus it is a survey about the doctrine called "legal status of parliamentary", which is a branch of public law that deals with institutions such as the immunity and inviolability of parliamentary seats, the ineligibility, the impeachment process of holding elective office, the prerogative of the forum and other topics relevant to the definition of the democratic principle in the Brazilian republic. Such institutions are essential to the operationalization of the state and it is possible to develop a research severally to each. However, without neglecting the importance of doctrinal and jurisprudential understanding of each of these points, this paper takes a step back and turn to a fundamental question that permeates the whole discussion of these institutes: the tense relationship between responsibility and freedom of parliamentarians.
\end{abstract}

eleição e procuram organizar as decisões do Estado consoante as exigências e as opiniões da sociedade, não há dúvida de que eles atuam nos dois âmbitos". Voto Min. Gilmar Mendes ADI 1.351/DF.

Revista da Faculdade Mineira de Direito, v.14, n. 27, jan./jun. 2011 - ISSN 1808-9429. 
Keywords: democracy, constitutional law, parliamentary autonomy, political representation.

\section{REFERÊNCIAS}

ALMEIDA, Fernanda Dias Menezes. Imunidades Parlamentares. Brasília. Câmara dos deputados. 1982.

ALEXY, Robert. Teoría de los derechos fundamentales. Madrid. Centro de Estudios Políticos y Constitucionales. 2002.

ATALIBA, Geraldo. Constituição e República. São Paulo. Malheiros. 2004.

BONAVIDES, Paulo. Ciência Política. São Paulo. Malheiros. 2006.

Política e Constituição. São Paulo: Forense. 1978.

BROSSARD, Paulo. O Impeachment, aspectos da responsabilidade do presidente da república. São Paulo. Saraiva. 1992.

Senado Federal. Ano 16. nº. 63. 1979.

Imunidade Parlamentar. Revista de Informação Legislativa. Brasília.

BOBBIO, Norberto. O futuro da Democracia. São Paulo. Paz e Terra. 2004.

BURKE, Edmund. Textos Políticos. México. Fondo de Cultura Econômica. 1996.

CANOTILHO, José Joaquim Gomes. Direito Constitucional. Coimbra. Almeida. $6^{\mathrm{a}}$ Edição.1993.

CALIMAN, Auro Augusto. Mandato Parlamentar. São Paulo. Atlas. 2005.

CAMPILONGO, Celso Fernandes. Representação política e ordem jurídica: os dilemas da democracia liberal. Tese de mestrado apresentada no departamento de Teoria Geral do Direito da Faculdade de Direito da Universidade de São Paulo. 1987.

COSTA, Tito. Cassação de Mandatos Eletivos Municipais. In Revista dos Tribunais. Ano 82. Janeiro de 1993. Volume 687.

Caggiano, Monica Herman Salen. O voto nas Américas, coord. Cláudio Lembo, org., Barueri, Minha Editora, 2008.

DUGUIT, Leon. Traité du Droit Constitutionel. Troisième Édition en cinq volumes. Tomes. II e IV. Paris. BOCCARD. 1928.

DWORKIN, Ronald. Levando os direitos a sério. São Paulo: Martins Fontes, 2007.

DUVERGER, Maurice. Os Partidos Políticos. Rio de Janeiro. Zahar. 1970.

FORTES, Luiz Roberto Salinas. Paradoxo do espetáculo: política e poética em Rousseau. São Paulo. FAPESP. 1997. 
Gil, Maria D’Alva. Representação política e sistema eleitoral no Brasil. São Paulo. Edições Símbolo. 1980.

HABERMAS, Jürgen. O discurso filosófico da modernidade. São Paulo. Martins Fontes. 2000 .

HESSE, Konrad. Elementos de Direito Constitucional da Republica Federal da Alemanha. Tradução da 20 Edição Alemã. Porto Alegre. Sergio Antonio Fabris Editor. 1998.

KELSEN, Hans. Teoria Geral do direito e do Estado. 3. ed. São Paulo. Martins Fontes. 2000.

FERREIRA FILHO, Manuel Gonçalves. Do Processo Legislativo. São Paulo. Saraiva. 2001. . A Democracia possível. São Paulo. Saraiva. 1978.

HAMILTON, Alexander; MADISON, James; JAY, John. O Federalista. São Paulo. Abril. 1985.

ILBERT, Courtenay Peregrine. EI Parlamento su historia, constitución y practica. Buenos Aires. Labor. 1930.

LOEWENSTEIN, Karl. Teoria de la constitución. Barcelona. Ariel. 1965.

LEFORT, Claude. Pensamento político. São Paulo. Paz e Terra. 1991

MARX, Karl. A questão judaica. São Paulo. Editora Moraes. 1991.

MONTEIRO, Washington de Barros. Curso de Direito Civil. São Paulo. Saraiva. 2003.

SCHIMITT, Carl. Théorie de la Constitution. Paris. PUF. 1993.

SOUSA, José Pedro Galvão de. Da representação política. São Paulo. Saraiva. 1971.

SILVA, José Afonso. Curso de Direito Constitucional Positivo. $24^{\text {a }}$ Edição, revista e atualizada nos termos da Reforma constitucional. São Paulo. Malheiros. 2005.

SILVA FILHO, Derly Barreto. O STF e o Controle dos Atos Parlamentares. São Paulo. Malheiros. 2003.

SILVA, Virgílio Afonso da. Sistemas Eleitorais, tipos efeitos jurídico-políticos e aplicação ao caso brasileiro, São Paulo, Malheiros, 1999.

REALE, Miguel. Decoro Parlamentar e cassação de mandato eletivo. In. Revista de Direito Público. São Paulo. RT. N. ${ }^{\circ} 10.1960$.

ROUSSEAU, Jean-Jaques. Do contrato sócial ou princípios do direito político. Tradução de Lourdes Machado. São Paulo. Abril Cultural. 1978

VIANNA, Oliveira. O idealismo da constituição. São Paulo: Companhia Editora Nacional. 1939. 